\title{
Race or Place? The Impact of News Depictions of Urban and Rural Poverty
}

\author{
Mandi Bates Bailey
}

Objective. While scholars have investigated how the race of welfare recipients in news portrayals affects attitudes toward welfare, few if any, have considered if the urban or rural setting of coverage contributes to or interferes with racial portrayals. Therefore, I investigate whether portrayals of poverty as either urban or rural or black or white perpetuate stereotypes and result in diminished support for welfare. Methods. I use a survey-based experiment that includes news stories about welfare where the race and place of the target are manipulated. Respondents received one of four treatments: urban black; rural black; urban white; or rural white. Results. I find that Anti-Black stereotypes and Anti-Urban stereotypes impact attitudes toward welfare policy and to a lesser extent attitudes toward welfare recipients. Conclusion. A consideration of place and race illustrates that situational and dispositional explanations of behavior provide a great deal of explanation for evaluations of welfare.

A pull-yourself-up-by-your-bootstraps mentality has long been prevalent in American society. However, Gilens (1999) finds that while whites' commitment to individualism helps drive opposition to welfare, the importance of such values is eclipsed by their negative views of blacks whom most whites (erroneously) believe to be the primary beneficiaries of welfare. While race provides a vital explanation, otherwise, the strong dislike for welfare policies goes unexplained. This study goes beyond focusing primarily on individualism and race by offering an explanation of attitudes toward welfare that includes place, or stereotypes of rural and urban Americans.

I present evidence that stereotypes of rural areas/poverty have the potential to impact attitudes toward welfare. For instance, stereotypes of rural residents may be positive, indicating that they possess the treasured value of individualism or that they work hard to rise above the limitations of their surroundings. Indeed, thirty-one percent of participants in a survey administered by the Kellogg Foundation identified "hardworking" as the term that best characterized rural America (Kellogg Foundation 2002). Moreover, Logan (1996) reports that Americans idealize rural America because it represents values such as hard work, family and community, that

Direct all correspondence to Mandi Bates Bailey, Department of Political Science, Valdosta State University, Valdosta, GA 31698 (mbbailey@valdosta.edu). The author would like to thank Jeff Fine, Richard Fording, Mark Peffley, Steve Voss, and Julie Zimmerman for helpful comments and suggestions.

Mandi Bates Bailey is Assistant Professor of Political Science at Valdosta State University.

The American Review of Politics, Vol. 33, Summer, 2012: 123-146

(c)2012 The American Review of Politics 
we see as lost in urban and suburban life. When these positive stereotypes are activated by the news media, it is reasonable to think they would lead to more positive evaluations of the rural poor. As such, this article strives to provide a more complete understanding of the determinants of attitudes toward welfare by utilizing a survey-based experiment that addresses place and race.

\section{Whom Do Americans Perceive to be Poor? Who are the Poor, Really?}

Who are the poor? Many Americans mistakenly believe that most welfare recipients are black. For instance, using data from the 1991 National Race and Politics Study (NRPS), Gilens (1999) finds that whites mistakenly believe that most $(60 \%)$ welfare recipients are black when in reality they comprise about 40 percent of welfare rolls. Further, according to the U.S. Department of Health and Human Services, in 1994 the percentage of white welfare recipients was narrowly greater than the percentage of black welfare recipients. Nevertheless, research suggests that welfare has become inherently linked to blacks impacting whites' attitudes toward welfare (see Gilens 1999; Mendelberg 2001; Quadagno 1994).

The connection between race and attitudes toward welfare has been studied extensively (e.g., Avery and Peffley 2003; Gilens 2003; Quadagno 1994). However, the connection between place and welfare has received much less attention, aside from noting that common conceptions of welfare mistakenly assume that most recipients live in urban areas (see Gilens 2003). To the contrary, poverty is dispersed among rural and urban areas. In fact, rural poverty has historically been more prevalent than urban poverty (Lichter and Crowley 2003). Studies also suggest rural households have a higher probability of becoming impoverished (Bosley and Mills 1999; Brown and Hirschl 1995; Dyk and Zimmerman 2000; Kickham et al. 2000; Schexnayder et al. 2001).

I assert that media perpetuate this inaccurate view of poverty. Media invariably present distorted images to convey certain story elements more efficiently (Iyengar 1991). For instance, photojournalists may look to neighborhoods where poor people are most concentrated when covering poverty and poor blacks tend to be more geographically concentrated than poor whites (Gilens 1999). In turn, poor black communities are more likely to be targeted by the media. Thus, understanding how people respond to news featuring blacks requires understanding how individuals use racial stereotypes to process political information.

Just as knowledge of racial stereotypes is needed to understand how individuals develop attitudes toward welfare and the poor, understanding 
attitudes toward urban and rural poverty requires knowledge of related stereotypes. Also, the tendency to look to homogenous "pockets of poverty" in the media emphasizes the need to address place. Therefore, I evaluate the link between media accounts, racial attitudes, and attitudes toward urban and rural residents.

I ultimately seek to determine if racial attitudes remain such dominant predictors of attitudes toward welfare when the previously omitted variable, place, is taken into account. Specifically, the current study considers whether Gilens' (1999) finding that Americans believe African Americans to be the undeserving recipients of welfare is confounded by a tendency to view black poverty as urban poverty. Therefore, if the dominant face of poverty is urban and black, we should evaluate the impact of both of these factors in determining attitudes toward welfare.

\section{Poverty in the News}

Clearly, a substantial number of people hold inaccurate perceptions of welfare recipients, and the news media are largely the sources of those misperceptions. Indeed, a growing body of research suggests the media perpetuate the belief that poverty is an urban, minority problem (Clawson and Trice 2000; Entman 1990; Entman and Rojecki 2000; Gilens 1999). For example, Gilens' (1999) study of print and broadcast media shows that since the mid-1960s blacks have been disproportionately portrayed (twice their actual proportions) as the targets in poverty stories and Entman and Rojecki $(2000,105)$ state that, “. . . merely showing a black person on the screen appears to be code for the involvement of poor people.” Similarly, Clawson and Trice's (2000) study of newsmagazines found that 96 percent of the poverty/welfare stories featured urban areas.

The staggering amount of urban poverty coverage and the neglect of rural poverty in the news imply that the poor have been misrepresented. But is this misrepresentation simply the result of ignoring rural poverty? In studying the evolution of poverty in the news, Gilens (1999; 2003) found that from 1950 until 1964, rural residents (specifically the white Appalachian coalfield) were the dominant faces of poverty in the news. After events such as the civil rights movement and the urban riots that occurred during the 1964-1968 period, however, news coverage of poverty shifted from sympathetic images of rural whites to less sympathetic coverage of urban blacks. Massy and Eggers (1990) corroborate this view in part by arguing that the publication of the Moynihan Report moved the focus of poverty from the rural South to the inner cities. However, through Gilens' examination it is difficult to determine if attitudes toward races or places governed 
opinions of the poor because images typically were of either rural whites or urban blacks.

The failure to consider the largely ignored rural poor in studies such as this one suggests further consideration of geography is necessary to determine whether attitudes toward welfare are driven by race, place, or both. I, therefore, extend Avery and Peffley's (2003) study by manipulating the race of the target photographically as they did, and I also address "place" by textually manipulating where the target lives (urban or rural area).

\section{Psychological Underpinnings}

I have considered misperceptions of the poor and the media's tendency to perpetuate those inaccuracies, but I have not yet addressed how media coverage may impact audiences. Research suggests that the news media have established urban blacks as the default image of the poor when poor blacks living in urban ghettos represent a very small portion of all poor Americans (Gilens 1999; 2003). Since we know that people apply racial stereotypes to form judgments when they are presented with this default image, it is also important to consider whether similar behavior occurs when the news story takes place in a rural setting (and whether racial stereotypes are undercut in these situations).

Stereotypes may impact judgments by biasing evaluations of whether welfare recipients are responsible for their economic conditions and whether they deserve assistance. If individuals see a group negatively, they tend to attribute failure to internal dispositional forces (e.g., laziness) and success to external transient factors, such as luck or ease (e.g., Weiner 1984). Similarly, Pettigrew (1979) describes what he calls the "Ultimate Attribution Error," a tendency to hold groups responsible for their relative advantage or disadvantage in life.

Attributions for a welfare mother's status may be dispositional or situational. Her poverty could be attributed to internal dispositions such as laziness or a preference for living on welfare versus getting a job (e.g., Avery and Peffley 2003; Gilens 1999). However, situational explanations for her condition would be external (i.e. environmental constraints). For instance, structural and societal conditions such as the failure of public transportation to get poor urbanites to jobs and an unwillingness on the part of some employers to offer jobs to black men can be blamed for urban poverty (Wilson 1996; see also Ellwood 1984; Patel and Kanthi 1986; Waxman 1983 for additional societal explanations). Situational explanations of poverty apply to rural areas where there is a lack of opportunity. Eleven percent of respondents in a Kellogg Foundation survey involving urban, suburban, and rural participants found a lack of job opportunities to be one of the most 
important problems facing rural America (Kellogg Foundation 2002). This study also states that respondents tend to view rural communities as committed to self-reliance and individualism. This sentiment could be seen to apply to Appalachian poverty as Auletta (1982) finds that in spite of their poverty, the rural Appalachian poor detest the idea of welfare and the stigma attached to those receiving it. Research also suggests this stigma is present in a rural California community where moral capital is linked to hard work and "welfare is almost always discussed with either disdain or shame" even though employment opportunities are scarce (Sherman 2006, 899).

It is common to overlook situational explanations for behavior and attribute behavior to internal dispositions, however (Eagly and Chaiken 1993; Nisbett and Ross 1980). Media frames also contribute to attribution errors (see Gilliam and Iyengar 2000). For instance, as indicated above, Gilens' (1999) extensive content analysis illustrated that the media tend to portray blacks as the undeserving poor (e.g., criminals), while whites in news reports tend to be portrayed as the victimized poor (e.g., elderly or rural whites). Hence, although stereotypes are not necessarily malicious (see Allport 1954), this discussion of their consequences suggests they can promulgate or at least perpetuate anti-black sentiments and/or anti-urban sentiments.

The existing literature demonstrates that stereotypes, particularly negative racial stereotypes, impact attitudes. I also have presented evidence that the stereotypical view of welfare recipients as urban blacks is inaccurate and that the media tend to reinforce this misconception. Such distortions have consequences. Accordingly, if Gilens (1999) is correct, the news media potentially lead white Americans to oppose welfare when they might not do so if they perceive the beneficiaries to be white. Alternatively, people may have entirely different conceptions of rural people, leading them to evaluate rural welfare recipients differently than urban recipients.

\section{Hypotheses}

I have presented four key premises. First, commonly held stereotypes of the poor are inaccurate. Second, the media appear to have reinforced these stereotypes by portraying the poor as disproportionately black and urban when poverty is dispersed among races and places. Third, while the media tend to ignore rural poverty, they have featured more sympathetic images of white and/or rural poverty in the past. Finally, while stereotypes of rural areas may be positive or negative, stereotypes of urban areas and of blacks are typically negative. These premises lead to testable hypotheses that address what happens when targets do and do not fit traditional stereotypes, and in turn, how judgments are affected. 
Peffley et al. (1997) find that black targets that were strongly inconsistent with traditional negative racial stereotypes prompted whites to "bend over backwards" in their evaluations. In other words, with coverage of black poverty that directly contradicts the stereotype (rural black targets rather than urban black targets), individuals rely less on the stereotype. Thus, I expect respondents to use more situational explanations when not confronted by urban black poverty.

Based on the foregoing, I reach three hypotheses. First, I hypothesize that the presentation of an urban black target is more likely than all of the other targets to activate negative stereotypes of both race and place resulting in more negative evaluations of welfare and welfare recipients. Alternatively, I hypothesize that the presentation a rural black welfare mother is less likely to activate negative racial stereotypes biasing evaluations of welfare than the presentation of an urban black welfare mother. In other words, respondents may be more likely to "bend over backwards" in their evaluations of welfare and the target because she is inconsistent with the traditional stereotype. Finally, I hypothesize that news featuring white welfare mothers is less likely to activate negative racial stereotypes biasing evaluations of welfare than news featuring black welfare mothers. Ultimately the analyses below provide mixed support for these hypotheses, however, they do stress that the limited view of poverty presented by the news media may not only contribute to inaccurate perceptions of the poor/welfare, but that this coverage may also bias evaluations of welfare.

\section{Data and Methodology}

To investigate the news media's ability to impact attitudes toward welfare and to test the above hypotheses, I have twice administered a twowave survey to students at a large public university in the South. The state in which the university is located is predominately rural with two primary urban areas. Greater than 75 percent of the sample is from this state. Therefore, this method of sample selection will help to maximize the likelihood that a substantial number of respondents have been exposed to rural poverty either directly or through the media. Contrastingly, a majority of survey participants (78.4\%) can be characterized as being urban. ${ }^{1}$ Also, this analysis is restricted to white respondents because the sample is predominately white (only 18 respondents identified as black).

\section{Sample Selection}

The samples of respondents in both waves of each application of the survey consist of undergraduate students from a variety of fields of study 
enrolled in introductory political science courses. These samples consist of 255 students in the first wave and 235 students in the second wave of the first application, and 170 students in the first wave and 160 students in the second wave of the second application.

Utilizing student samples such as this is a common practice among social scientists. However, when discussing social psychologists' reliance on student samples, Sears (1988) argues that such samples may suffer from compromised external validity because they are not representative of the adult population. These biases may apply to the sample utilized here; however, I have chosen this sample for two reasons. First, research suggests that concerns about student samples are overstated (Greenberg 1987; Kuhberger 1998) and recent examples of experimental research rely on student samples (e.g., Best and Hubbard 1999; Druckman 2001; 2003; Druckman and Nelson 2003; Nelson et al. 1997). Secondly, because of the embedded manipulation, completion of the survey will likely take more time than most people are willing to invest, necessitating a captive audience. By administering the survey to students during classes, I was able to exert more control over its administration, making sure that the same individual completed the survey weeks later, subjects read the news stories, and that the completed surveys are genuine.

\section{Experimental Manipulation}

I administered the waves of each survey application approximately six weeks apart. They were virtually identical with the exception of the news media manipulation and the related questions that were included in the second wave. Therefore, I am able to gauge attitudes some time before reactions to the experimental manipulations of welfare. Rather than embedding the manipulation within the survey as Avery and Peffley (2003) did, this pretest/posttest design minimizes any tendency of the questions in the pretest from "priming" responses to questions about the news story in the posttest. In other words, by collecting respondents' attitudes toward race and place weeks before applying the stimulus, I can be more confident that the collection of those attitudes did not bias their evaluations of the target.

Avery and Peffley (2003) used a two-by-two design that varies both the race (black or white) of the mother and child depicted photographically and the tone of the article (i.e., was welfare reform described as a success or a failure?). I incorporate the race variation as well as a variation of place (urban or rural). Results then reflect reactions to one of the following conditions: 1.) Black Target, Rural Setting; 2.) Black Target, Urban Setting; 3.) White Target, Rural Setting; and 4.) White Target, Urban Setting. These considerations are evident through the manipulations of the text and staged 
photos. To minimize extraneous factors that could influence responses, the photos have the same neutral background with either a black mother and son or a white mother and son (the mothers are approximately the same age as are the sons) as the targets. Place is addressed by manipulating the text of the articles. Articles are presented in an identifiable city (Chicago, IL) or in a rural area (Brumley Gap, VA). As rural areas are not typically identifiable, care has been taken to convey rurality without altering the substance of the article. The targets in each article are also given names associated with African-American heritage (Keeya Johnson and son, DeShawn) or more traditional Anglo-American names (Carrie Miller and son, Charles). This manipulation is included to assure readers that the targets do belong to particular racial groups as "black names" can lead to negative evaluations (Bertrand and Mullainathan 2003).

While the same photos were used, the 2004 and 2005 versions of the survey are different. The article text in the second wave of the 2004 survey was adapted from a Boston Globe story related to family struggles during the holidays. This may seem to elicit sympathetic responses, but it is a known bias and the link to the holiday season is useful given when the surveys were administered (i.e., there is a reason the article would surface this time of year). Yet, the use of the altered Boston Globe story would have seemed inappropriate and contrived for the second wave of the 2005 survey as it was administered after the holidays. Therefore, the 2005 survey contains an article about a decline in the number of state (Illinois or Virginia) residents receiving welfare.

The instruments elicit, among other opinions, respondents' attitudes toward the welfare mothers presented in the articles they read as well as welfare policy. Specifically, of four questions asked after respondents read the news article, two are aimed at evaluations of the welfare recipient and two are aimed at evaluations of welfare policy.

The key independent variables include various measures of stereotypes. These stereotype measures address respondents' previously held attitudes toward blacks, whites, rural residents and urbanites. I constructed these measures from responses to questions about racial and geographic (urban or rural) groups gathered in the first wave of the survey. Borrowing from Virtanen and Huddy (1998) and Hurwitz and Peffley (1997), I construct a black stereotype index by asking survey respondents whether they see blacks as lazy or hardworking as well as whether they see blacks as preferring to live off welfare or preferring to be self-supporting on two semantic differentials. $^{2}$ Hurwitz and Peffley $(1997,382)$ refer to laziness and violence as "central attributes" that "capture whites' resentment toward blacks." Accordingly, to assess that resentment toward blacks, respondents in this study were asked to reveal their specific feelings about groups on a series of seven-point 
semantic differential scales ranging from what are typically considered more negative characteristics (lazy) to what are typically considered more positive characteristics (hardworking). These various groups were (in order) whites, blacks, people from cities, and people from the country (rural areas). This approach enabled me to construct a white stereotype index in the same way. Moreover, I extended their approach by creating urban and rural stereotype indexes from asking the same questions about these groups.

I combined these stereotype measures to form stereotype difference scales that capture individuals' ratings of one group relative to another. Specifically, the stereotype difference measure, Anti-Black Stereotype, is created to take into consideration respondents' stereotypes of blacks and whites in relation to each other, while the stereotype difference measure, Anti-Urban Stereotype, is created to take into consideration respondents' stereotypes of urbanites and rural residents in relation to each other. This approach is based, in part, on an Anti-Black Prejudice scale created by Soss et al. (2003). Because my racial stereotype measure is based strictly on items measuring beliefs about blacks relative to whites, it is labeled Anti-Black Stereotype. I extend this logic to the measure of Anti-Urban Stereotype.

\section{Model Specification and Survey Measures}

The analyses below provide both encouraging and mixed support for this study's hypotheses concerning when stereotypes will be activated and how they will influence evaluations of the target and welfare policy. Specifically, for three of the four dependent variables, stereotypes are activated by particular news portrayals of welfare mothers, and consequently, evaluations of the target and welfare policy are biased by the stereotypes. Below, I provide a more detailed discussion of the independent and dependent measures in the analysis before turning to the regression results.

I have argued that when citizens consume news stories of poverty, their reactions to those stories are shaped by the way welfare recipients are depicted in the news (i.e., the race and the place of the welfare mother in the story), as well as their stereotypes of blacks versus whites and people from urban versus rural areas. Of course, citizens' reactions to poverty stories also are impacted by factors such as their partisanship and various demographic characteristics known to influence judgments toward welfare and welfare recipients. Accordingly, such "controls" need to be included to eliminate any spurious effects. In the analyses below, therefore, each of the four dependent measures of welfare judgment is regressed on several predictors:

Welfare Judgment $=$ Anti-Black Stereotype + Anti-Urban Stereotype + Controls + Race Manipulation + Place Manipulation + 


\begin{abstract}
Race*Anti-Black Stereotype + Place*Anti-Black Stereotype + Race*Anti-Urban Stereotype + Place*Anti-Urban Stereotype + Race*Controls + Place*Controls.
\end{abstract}

To capture the impact of the manipulation of race and place on welfare judgments, two dummy variables were created: Race Manipulation, scored as 1 if the respondent received a news article featuring a white target and 0 otherwise; and Place Manipulation, scored as 1 if the respondent received a news article featuring a rural target and 0 otherwise. The treatment dummies are interacted with all the predictors in the equation above to assess whether the influence of the predictors is significantly different across the four experimental conditions. Given the coding of the variables, the "main effects" of the predictors in the equation above refers to the impact of the predictors when the welfare mother is black and lives in an urban area (this is the condition when both manipulation dummies equal 0 ).

Because the theoretical development of this study links attitudes toward welfare to racial stereotypes and I contend they are linked to stereotypes of places, stereotype measures should consider comparative assessments of blacks versus whites and urbanites versus rural people. Racial stereotypes are thus captured by the measure of Anti-Black Stereotype, which is assessed by subtracting stereotypes of whites from stereotypes of blacks (i.e., Black Stereotype - White Stereotype); ${ }^{3}$ and Anti-Urban Stereotype, which is assessed by subtracting stereotypes of rural people from stereotypes of urbanites (i.e., Urban Stereotype - Rural Stereotype). ${ }^{4}$ Specifically, in constructing the Anti-Black Stereotype measure, the coding of the Black and White Stereotype scales was first reversed so that higher values represent more negative evaluations of the groups. Scores on the White Stereotype scale were then subtracted from the Black Stereotype scale so that higher values on the resulting Anti-Black Stereotype scale indicate more negative evaluations of blacks than whites. I followed a similar strategy with AntiUrban Stereotype so that higher values represent more negative stereotypes of urbanites in relation to rural people. This approach finds that nearly fiftyfive percent of respondents hold varying degrees of Anti-Black affect while fifty-two percent of respondents hold varying degrees of Anti-Urban affect.

There are two advantages of these stereotype measures. First, they allow for a more parsimonious specification that includes just two stereotype measures in the analyses versus individual measures of stereotypes toward each of the four groups (blacks, whites, urban, and rural), which would introduce a high collinearity among the predictors. Second, such difference scores control for the possibility that individuals who rate blacks (urbanites) negatively may be misanthropic in that they rate both whites and (rural people) and blacks (urbanites) negatively. 
Because research suggests that the population density of where an individual is from may impact attitudes (Glenn and Hill 1977), I include the urban/rural respondent identification measure $(1=$ urban $)$. As some individuals may perceive a particular area to be urban while others may see the same area as rural, respondents were asked to identify the county and state they were from in order to determine whether they qualified as urban or rural.

As noted above, two versions of the survey manipulation are utilized. Version is a dummy variable (2005 Survey/Version 2 = 1). I examined results for each of the versions separately. I did not find any systematic differences in the antecedents of responses to the two versions. Therefore, because there were so few cases analyzing versions separately, they are pooled. Version is included as a control in order to account for higher mean evaluations in the Holiday (2004) application, however. Many of the analyses reported below reveal statistically significant relationships between the dependent variable and the version of the survey. Aside from raising average evaluations of the dependent measures, does the relative impact of the other antecedents (especially the stereotype variables) vary across the two versions of the survey? For the most part, the answer to this question is a qualified, no. ${ }^{5}$

The four dependent variables mirror those used by Avery and Peffley (2003) and are appropriate here because they consider both respondents' attitudes about the targets of welfare they see in news depictions and subsequent evaluations of welfare policy. The first two dependent measures tap respondents' opinions about the welfare mother presented in the articles. First, I consider respondents' judgments of whether the welfare recipient or the welfare system should be "blamed" if the welfare mother loses her job. Responses are coded on a seven-point scale from "Failure of the Woman" (1) to "Failure of Welfare Reform" (7). Thus, a response of 1 indicates that survey participants attribute going back to welfare to dispositional or internal factors (i.e., the fault of the target), whereas a response of 7 indicates attribution to situational factors. The coding of this measure, labeled "Blame the Target," was reversed so that higher values reflect more of a tendency to blame the welfare mother depicted in the news account.

The second dependent measure, "Go Back on Welfare," asks "If the woman in the article lost her job would you guess she is more likely to try hard to look for a new job or try to go back on welfare?” Responses are coded on a seven-point scale from "Try hard to look for a new job" (1) to "Go back on welfare" (7). This variable addresses dispositional/situational explanations of beliefs because it assesses the target's work ethic as a predictor of her future behavior. 
The third and fourth dependent variables tap respondents' evaluations of welfare policy, as opposed to the beneficiaries. These questions are useful for two reasons. First, respondents may be uncomfortable evaluating, or may be unable to evaluate, targets (e.g., they may ask how they are capable of evaluating someone they don't know that lives somewhere with which they are unfamiliar). Secondly, responses to evaluations of the targets may suffer from social desirability bias and participants may not express their true preferences. Thus, asking respondents to evaluate welfare policies after reading the manipulation avoids these problems while still allowing for the assessment of their stereotypes on evaluations. The dependent variable labeled "5-Year Limit" is measured by asking respondents if they think a limit of five years of welfare assistance is too short (1), too long (7), or about right (4). Similarly, the final dependent variable I use is referred to as "Welfare Spending" which ascertains whether respondents would prefer to see a decrease (1), an increase (7), or the same amount of money spent on welfare as it has been (4).

\section{Results}

I now turn to estimating the full equation specified above with ordinary least squares procedures and then to computing the coefficients for each of the four experimental conditions.

\section{Dependent Variable: Blame the Target}

To investigate how racial stereotypes and stereotypes related to place vary across the four treatments, I begin by considering whether respondents are more or less likely to blame the target rather than the welfare system if she loses her current job. As indicated above, I expect respondents with higher scores on the Anti-Black and Anti-Urban Stereotype measures to place more weight on dispositional factors than situational factors, especially when evaluating black or urban welfare mothers versus welfare mothers depicted as white or rural. In other words, I expect the presentation of black and/or urban targets to activate negative stereotypes and result in more of a willingness to place blame on the target. Table 1 presents the results of this analysis. The key independent variables of interest (Anti-Black Stereotype and Anti-Urban Stereotype) fail to reach statistical significance in three of the four treatments.

However, as the second column in Table 1 under "Blame the Target" illustrates, there is a statistically significant relationship (at the .1 level) between Anti-Black Stereotype and "Blame the Target" among those respondents receiving the urban black treatment. While this finding does not 


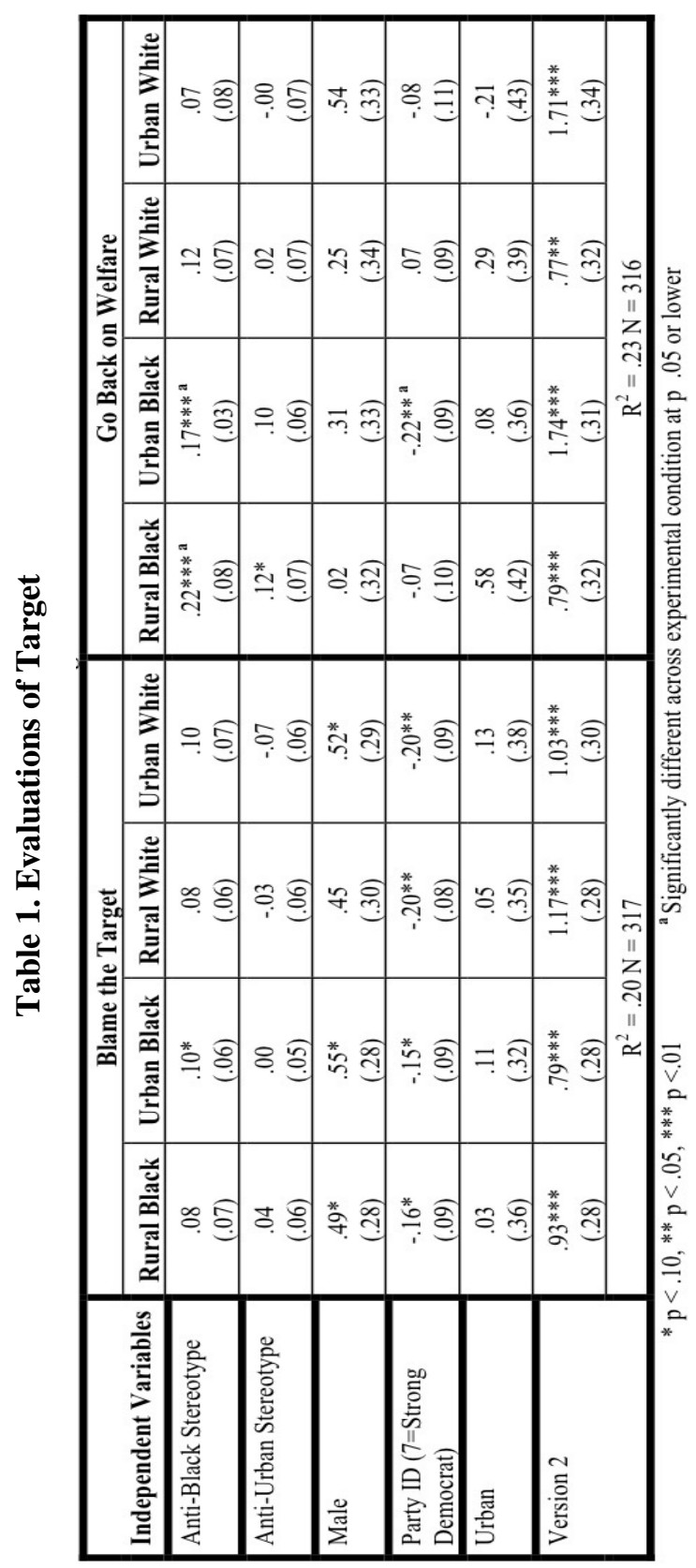


achieve significance at the more conventional .05, it nevertheless implies that respondents receiving the urban black manipulation with more negative stereotypes of blacks in relation to whites are more likely to blame the target rather than the welfare system for the target's potential return to welfare. The model then seems to provide support for this study's expectations because in the treatment that is most typical of news coverage respondents are evaluating the target in dispositional terms which results in a significantly more negative evaluation of the urban black welfare mother. Yet, the impact of the Anti-Black Stereotype variable does not vary significantly across the conditions of the experiment. Thus, although there appears to be support for the hypothesis that urban black targets are more likely than all other targets to activate negative stereotypes biasing evaluations of welfare, we must cautiously interpret these findings. Moreover, while there is some support for this hypothesis because negative racial attitudes appear to impact respondents' willingness to blame the target, it is important to note that Anti-Urban Stereotype fails to achieve statistical significance.

Table 1 also reveals that party identification, gender, and the version of the survey are significant predictors. In three of the four manipulations, gender is significantly related to the dependent variable, suggesting that men are more likely to blame the target rather than the welfare system than are women. This finding is consistent with expectations because women are typically more sympathetic than men. The version of the survey, on the other hand, is statistically significant in all four manipulations with respondents receiving the first version (Holiday/2004) being more sympathetic toward the welfare mother than respondents receiving the second version (2005). Similarly, party identification is significantly related to the dependent variable across all four treatments, illustrating that Republicans are more likely to attribute blame to the target rather than the welfare system. Whether the respondent is from an urban or rural area is not significantly related to "Blame the Target" in any of the four treatments.

\section{Dependent Variable: Go Back on Welfare}

As with "Blame the Target," "Go Back on Welfare" also addresses evaluations of the target. Unlike "Blame the Target," however, analyses of "Go Back on Welfare" produced statistically significant findings regarding both Anti-Black Stereotype and Anti-Urban Stereotype.

Table 1 provides further support for this study's expectations regarding "Go Back on Welfare." Specifically, when the target is black as opposed to white (regardless of place) respondents with more negative stereotypes of blacks in relation to whites are more likely to infer that the target will go back on welfare rather than trying hard to find a new job. These relation- 
ships are significantly related to "Go Back on Welfare" at .01. These findings comport with this study's expectations that negative racial stereotypes, impact attitudes toward welfare and condition negative evaluations of black welfare recipients. They are also consistent with Gilens (1999) and Avery and Peffley (2003).

The results also show that respondents receiving the rural black manipulation are more likely to perceive the target as going back on welfare rather than trying hard to look for a new job if they possess more negative stereotypes of urbanites relative to people in rural areas. This finding may be related to the tendency to "bend over backward" in evaluations of targets that are inconsistent with preexisting stereotypes. In other words, respondents receiving this manipulation may be responding to either positive rural stereotypes or the fact that rural black poverty is inconsistent with their perceptions of poverty.

The version of the survey is statistically significant across all conditions and party identification is significantly related to the dependent variable in the expected direction (Republicans are more likely to think the former welfare mother would return to welfare rather than trying hard to look for a new job if she lost her current job) in the urban black manipulation. Gender and whether the respondent is from an urban/rural area are not significantly related to "Go Back on Welfare."

\section{Dependent Variable: 5-Year Limit}

"5-Year-Limit" and "Welfare Spending" are used to assess respondents' judgments of the welfare system rather than their judgments of the targets after being exposed to the news manipulations. Table 2 presents the results of the analysis involving 5-Year-Limit within each of the four experimental manipulations. These analyses reveal an interesting dichotomy. Here we see that Anti-Black Stereotype is only significantly related to the dependent variable when the target is presented as black and Anti-Urban Stereotype is only significantly related to the dependent variable when the target is portrayed as white.

Table 2 reveals the same strong significant relationship (at the .01 level) between Anti-Black Stereotype and 5-Year-Limit among respondents receiving treatments with black targets as seen above. Thus, conforming to expectations, respondents seeing a black welfare mother are more likely to think that a 5-year-limit on welfare assistance is too long if they hold more negative stereotypes of blacks. The relationship between 5-Year-Limit and Anti-Black Stereotype is not significant when respondents see a white target. Additionally, the difference in the impact of Anti-Black Stereotype across the race of the target is significant at the .05 and .01 levels. 


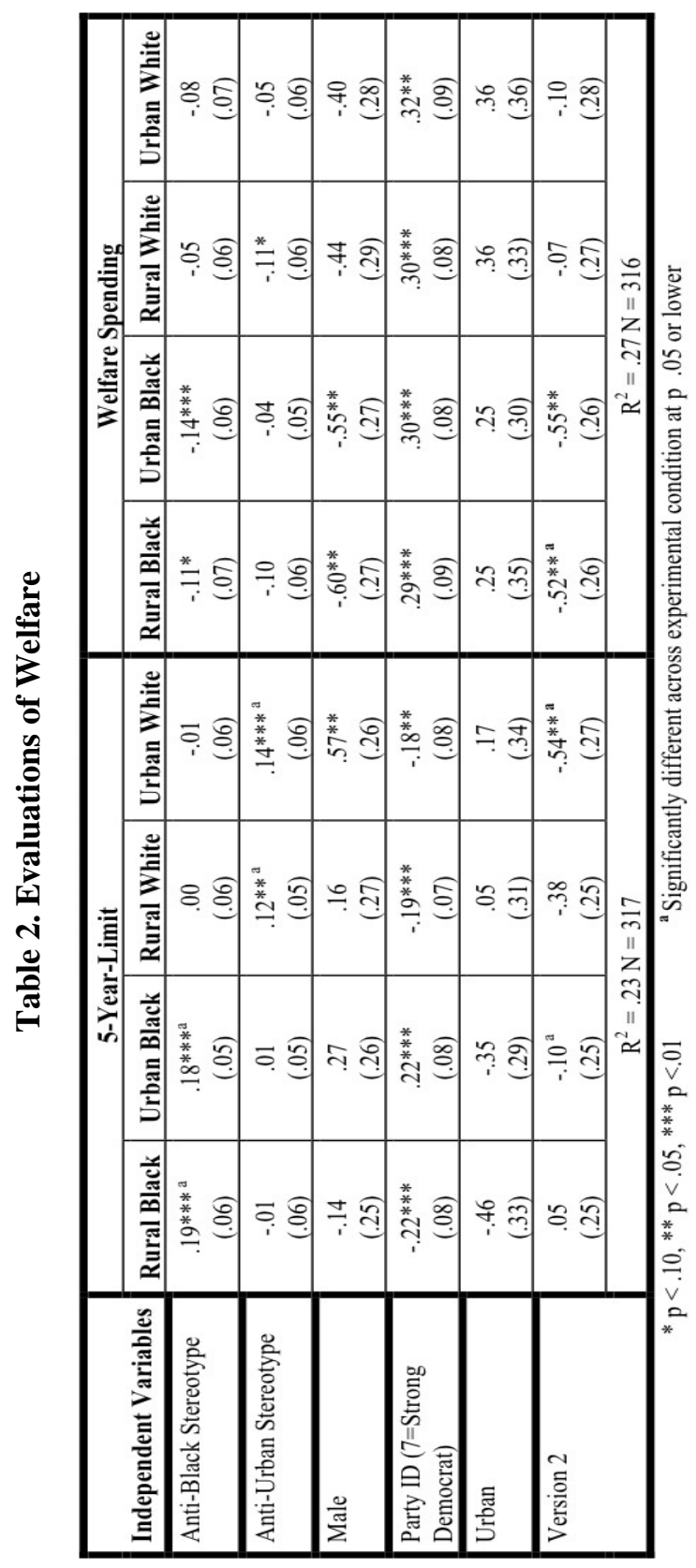


Alternately, respondents viewing white targets are more likely to see the welfare limit as too long if they hold more negative evaluations of urbanites relative to rural people. This relationship between Anti-Urban Stereotype and 5-year-Limit reaches significance at the conventional .05 level in the rural white manipulation and the .01 level in the urban white manipulation. The relationship between Anti-Urban Stereotype and 5-Year-Limit is not significant in either of the black manipulations. I do not argue that rural white poverty is now the dominant image, but rather that it is more consistent with respondents' notions of poverty than are images of rural blacks. I also contend that while there is no one image of rural and there are positive and negative stereotypes associated with rural areas, respondents will be more sympathetic to rural people than urbanites. The impact of the place stereotype also varies significantly with the race of the target. Party identification is significant across all treatments (Republicans are more likely to perceive the five year limit as too long). Gender and version are significant only in the urban white treatment. Again, whether the respondent is from an urban or rural area is not significantly related to the dependent variable.

In addition to revealing significant relationships between 5-Year-Limit and the key independent variables of interest, Table 2 also shows statistical significance across treatments. Specifically, the first row of coefficients in Table 2 (related to 5-Year-Limit) assessing the impact of respondents' AntiBlack Stereotypes illustrates that respondents receiving the urban black treatment are more likely than respondents receiving other treatments to perceive a 5-year-limit on welfare assistance as too long if they hold more negative stereotypes of blacks. This is the only finding in the analyses of all four dependent variables that illustrates a statistical significance across treatments. However, given the small number of observations per manipulation, it is difficult to achieve statistically significant effects for the interactions.

\section{Dependent Variable: Welfare Spending}

Results of the "Welfare Spending" analysis indicate that, like 5-YearLimit, respondents encountering black as opposed to white targets are more likely to have their Anti-Black Stereotypes activated. Table 2 illustrates that among respondents that read news articles featuring black targets those with more negative stereotypes of blacks, versus whites are more likely to indicate a preference for a decrease in welfare spending. This relationship is significant at the .1 level in the rural black treatment and at the .01 level in the urban black treatment. These findings conform to expectations as presentations of black targets appear to be biasing evaluations of welfare. 
Anti-Urban Stereotype is significantly related to the dependent variable in only the rural white manipulation (at the .1 level). In this instance, respondents receiving the rural white manipulation are more likely to have their Anti-Urban stereotypes activated than those receiving the remaining manipulations. More specifically, respondents receiving this treatment with more negative stereotypes of urbanites in relation to rural residents are more likely to think the federal government should decrease welfare expenditures. However, the impact of the racial stereotype is not statistically significant across the experimental conditions.

Anti-Urban Stereotype is statistically significant at the .1 level in the rural white manipulation. This indicates that the greater their negative stereotypes of urbanites relative to rural residents, the more likely respondents are to indicate a preference for a decrease in welfare spending. Once again, I find support for this study's assertion that stereotypes of places as well as races impact evaluations of welfare. In this case, I would expect respondents to attribute the condition of welfare to more situational factors because they have just encountered a rural target (as described above). Moreover, the target they encountered was white; therefore, their images of poverty (urban black and rural white) were not compromised. In turn, respondents are able to process the information contained in the article and the survey questions by comparing the situations they perceive urbanites to face and the situations they perceive rural residents to face. Anti-Urban Stereotype is sensitive to this process and the findings support the study as greater Anti-Urban Stereotype is related to respondents' opposing greater welfare spending.

Gender (in black treatments) and Party ID (in black treatments and the rural white treatment) are significantly related to "Welfare Spending" (Women and Democrats are more likely to indicate preferring an increase in spending.). Version is significant in the black manipulations while the relative context measure is not. The impact of the place stereotype is not significant.

\section{Summary and Implications}

Results are summarized below and are separated based on evaluations of welfare recipients and evaluations of the welfare system. A discussion of the implications of these findings follows.

\section{Evaluations of Welfare Recipients}

The two variables addressing attitudes toward welfare recipients, "Blame the Target” and "Go Back on Welfare," provide mixed support for 
the hypotheses noted above. Analyses of "Blame the Target" only produce one significant finding regarding the key independent variables. This finding that respondents receiving the urban black manipulation with more negative stereotypes of blacks are more likely to blame the target rather than the welfare system for the her potential return to welfare provides support for this study. It is important to note that while this relationship fails to reach statistical significance at the .05 level (it achieves statistical significance at the .1 level), it remains important because "Blame the Target" directly asks respondents to evaluate how responsible they perceive the target to be for her poverty. And, in this case, only the urban black treatment appears to activate negative racial stereotypes. The rural black treatment does not appear to activate these stereotypes.

Analyses of "Go Back on Welfare" also provide results that conform to my expectations. As noted above, results concerning both of the black treatments suggest that the more negative respondents' stereotypes of blacks in relation to whites, the more likely respondents are to perceive the target as going back on welfare. Thus, respondents appear to be using a more dispositional evaluation of black targets. Additionally, we see that in the rural black condition respondents are more likely to perceive the target as going back on welfare rather than trying hard to look for a new job if they have more negative stereotypes of urbanites versus people living in rural areas. This finding also conforms to my expectations that stereotypes of rural residents are likely to be more positive than stereotypes of urbanites.

\section{Evaluations of Welfare Policies}

Both of the measures designed to capture attitudes toward the welfare system provide support for the hypothesis that respondents will be more sympathetic toward white targets and less sympathetic toward black targets resulting in diminished support for welfare.

The "5-Year Limit" analyses show that the greater respondents' negative stereotypes of blacks compared to whites, the more likely they are to see the limit as too long when presented with a black target (urban or rural). Moreover, these results suggest that the greater their negative stereotypes of urbanites relative to rural residents, the more likely respondents are to think the 5-year limit is too long when presented with either an urban white or a rural white target. There is also statistical significance across conditions in this analysis indicating that respondents receiving the black treatments are more likely than respondents receiving the white treatments to see a 5-year-limit on welfare assistance as too long if they hold more negative stereotypes of blacks. 
With regard to "Welfare Spending," finding that among respondents that read news articles featuring black targets (both urban and rural), those with more negative stereotypes of blacks versus whites are more likely to indicate a preference for a decrease in welfare spending provides support for this study. Also, these results suggest that the greater their negative stereotypes of urbanites as compared to rural residents, the more likely respondents are to indicate a preference for a decrease in welfare spending when confronted by a rural white target. This is further support for this study because it indicates a tendency to assess urban poverty negatively.

\section{Implications}

The roles of situational and dispositional explanations of behavior provide a great deal of explanation for the evaluations of the targets in these experimental manipulations. However, I have not yet adequately addressed the implications of the evaluations of the welfare system.

The results above involving evaluations of the target provide mixed support for this research while findings involving the welfare system are much more definitive. What can explain this difference? To begin, evaluations of individual welfare mothers may be very difficult for respondents. For instance, it may be very difficult for respondents to try to anticipate what an individual welfare mother is likely to do based on a brief description in a newspaper article. It is also possible that respondents may have reacted to the questions about the welfare mother more suspiciously. That is, individuals with more negative stereotypes of blacks may be less willing to provide negative evaluations of black welfare mothers because they feel their responses will be interpreted as politically incorrect, or even racist. For instance, using unobtrusive measures of prejudice in their "List Experiment," Kuklinski et al. (1997) find that racial prejudice is higher for such measures than it is for survey items that ask explicitly about race or blacks.

Responses to survey questions aimed at the welfare system generally do not seem to elicit the same negative affect. This is the foundation for Gilens' (1999) notion that welfare is "racially coded.” Additionally, the concept of symbolic racism (e.g., Kinder and Mendleberg 2000; and Sears et al. 2000), which includes the ideas that whites perceive blacks as a threat to traditional American values, that blacks continue to receive undeserved benefits, and that socialization continually reinforces these stereotypes, indicates that whites can mask their negative affect toward blacks by opposing policies they believe benefit blacks. Therefore, news manipulations may activate stereotypes, but respondents are more comfortable expressing their true preferences when they are not so obviously linked to negative evaluations of blacks. 
Finally, I remind the reader that significant results regarding AntiBlack Stereotype are confined to the black manipulations and significant results regarding Anti-Urban Stereotype are largely confined to the white manipulations (excluding the rural black treatment in the "Go Back on Welfare" treatment). Recall the earlier discussion about the evolution of poverty coverage where the focus shifted from sympathetic coverage of rural whites to less sympathetic coverage of urban blacks. It is reasonable to assume that sympathetic views of rural white poverty and unsympathetic views of urban black poverty have persisted and impact individuals' assessments of the welfare accordingly, linking rural poverty to white poverty and black poverty to urban poverty. Alternatively, these analyses may have revealed that negative racial stereotypes undercut negative urban stereotypes when targets are black but when targets are white and negative racial stereotypes are not activated, respondents may be more likely to rely on stereotypes of place.

In sum, future studies assessing evaluations of welfare and welfare recipients can build upon this research. It has endeavored to explain the antecedents of these evaluations by focusing on both race and place. In doing so, it has underscored the need to look at the context, or physical location, in which media portrayals of welfare take place as well as the race of the targets. Because individuals have varied stereotypes of places as well as races, particularly as they relate to evaluations of welfare and welfare recipients, the impact of place should not be neglected in future studies of this kind.

\section{NOTES}

${ }^{1}$ The state data center determines whether a county is urban or rural by comparing the number of urban residents to the number of rural residents. If the urban residents outnumber the rural residents (based on the 2000 census), the county is considered urban and vice versa. Respondents were asked to indicate the state and county in which they were from and the state data center's approach was used to determine whether respondents (both in-state and out-of-state) were from urban or rural areas.

${ }^{2}$ Virtanen and Huddy (1998) include a measure of patriotism in their "old fashioned racism" measure that I do not include.

${ }^{3}$ Anti-Black Stereotype $=($ Black Stereotype $)-($ White Stereotype $)$, where:

Black Stereotype $=($ Blacks as Lazy vs. Hardworking $)+($ Blacks as Preferring to Live Off Welfare vs. Preferring to be Self-Supporting); and White Stereotype = (Whites as Lazy vs. Hardworking) + (Whites as Preferring to Live Off Welfare vs. Preferring to be SelfSupporting)

${ }^{4}$ Anti-Urban Stereotype $=($ Urban Stereotype $)-($ Rural Stereotype $)$, where:

Urban Stereotype $=($ Urbanites as Lazy vs. Hardworking $)+($ Urbanites as Preferring to Live Off Welfare vs. Preferring to be Self-Supporting); and Rural Stereotype = (Rural 
Residents as Lazy vs. Hardworking) + (Rural Residents as Preferring to Live Off Welfare vs. Preferring to be Self-Supporting)

${ }^{5}$ These results are not presented here because they contain too few observations ( $\mathrm{N}$ is less than 50 in 29 of 32 models estimated) to obtain reliable regression results. In analyses such as these with so few observations, a small amount of collinearity between independent variables can produce odd results that capitalize on chance. In sum, with so many estimated equations with so few cases, the findings are not consistent or reliable enough to be useful.

\section{REFERENCES}

Allport, Gordon W. 1954. The Nature of Prejudice. Garden City, NY: Addison-Wesley Publishing.

Auletta, Ken. 1982. The Underclass. New York: Random House.

Avery, James M., and Mark Peffley. 2003. Race Matters: The Impact of News Coverage of Welfare Reform on Public Opinion. Pp. 131-150 in Race, Welfare, and the Politics of Reform, eds. Sanford Schram, Joe Soss, and Richard Fording. Ann Arbor: University of Michigan Press.

Bertrand, Marianne, and Sendhil Mullainathan. 2003. Are Emily and Greg More Employable than Lakisha and Jamal? A Field Experiment on Labor Market Discrimination. National Bureau of Economic Research. Working Paper No. 9873. July 2003.

Best, Samuel J., and Clark Hubbard. 1999. Maximizing "Minimal Effects": The Impact of Early Primary Season Debates on Voter Preferences. American Politics Quarterly 27:450-467.

Bosley, Sarah, and Bradford Mills. 1999. How Welfare Reform Impacts Non-Metropolitan and Metropolitan Counties in Virginia. Virginia Tech Rural Economic Analysis Programs. September 1999. Available at www.reap.vt.edu/publications/reports/ r46.pdf.

Brown, David L., and Thomas A. Hirschl. 1995. Household Poverty in Rural and Metropolitan-Core Areas of the United States. Rural Sociology 60(3):44-66.

Clawson, Rosalee A., and Rakuya Trice. 2000. Poverty as We Know It. Public Opinion Quarterly 64:53-64.

Druckman, James N. 2001. On the Limits of Framing Effects: Who Can Frame? Journal of Politics 63:1041-1066.

Druckman, James N. 2003. The Power of Television Images: The First Kennedy-Nixon Debate Revisited. Journal of Politics 65:559-571.

Druckman, James N., and Kjersten R. Nelson. 2003. Framing and Deliberation: How Citizens' Conversations Limit Elite Influence. American Journal of Political Science 47:729-745.

Dyk, Patricia H., and Julie N. Zimmerman. 2000. The Impacts and Outcomes of Welfare Reform across Rural and Urban Places in Kentucky. Final report. Policy Outcome Grant. Submitted to the U.S. Department of Health and Human Services, Assistant Secretary for Planning and Evaluation. http://www.ca.uky.edu/snarl/WelfareReform/ WelfRefResearchReport/WelfareReformResearchIndex.htm (July 22, 2011).

Eagly, Alice H., and Shelly Chaiken. 1993. The Psychology of Attitudes. Fort Worth, TX: Harcourt College Publishers.

Ellwood, David T. 1984. The Hope for Self-Support. In The State and the Poor in the 1980s, eds. Manuel Carballo and Mary J. Bane. Boston, MA: Auburn House. 
Entman, R.M. 1990. Modern Racism and the Images of Blacks in Local Television News. Critical Studies in Mass Communication 7:332-346.

Entman, Robert M., and A. Rojecki. 2000. The Black Image in the White Mind: Media and Race in America. Chicago: University of Chicago Press.

Gilens, Martin. 2003. How the Poor Became Black: The Racialization of American Poverty in the Mass Media. Pp. 101-130 in Race, Welfare, and the Politics of Reform, eds. Sanford Schram, Joe Soss, and Richard Fording. Ann Arbor: University of Michigan Press.

Gilens, Martin. 1999. Why Americans Hate Welfare: Race, Media, and the Politics of Antipoverty Policy. Chicago: University of Chicago Press.

Gilliam, Franklin D., and Shanto Iyengar. 2000. Prime Suspects: The Influence of Local Television News on the Viewing Public. American Journal of Political Science 44:560-573.

Glenn, Norval D. and Lester Hill. 1977. Rural-Urban Differences in Attitudes and Behavior in the United States. The Annals of the American Academy of Political and Social Science 429(1):36-50.

Greenberg, Jerald. 1987. The College Sophomore as Guinea Pig: Setting the Record Straight. The Academy of Management Review 12(1):157-159.

Hurwitz, Jon, and Mark Peffley. 1997. Public Perceptions of Race and Crime: The Role of Racial Stereotypes. American Journal of Political Science 41(4):375-401.

Iyengar, Shanto. 1991. Is Anyone Responsible? How Television Frames Political Issues. Chicago: University of Chicago.

Kellogg Foundation. 2002. Perceptions of Rural America. Battle Creek, MI: Kellogg Foundation.

Kickham, Kenneth, Robert Bentley, Nury Effendi, and Angela Harnden. 2000. Health and Well-Being in Oklahoma: A Long Term Analysis of Welfare Reform. Oklahoma Department of Human Services. May 2000. Available at www.okdhs.org/ ifinance/Research Studies/TANF May2000.htm.

Kinder, Donald R., and Tali Mendleberg. 2000. Individualism Reconsidered: Principles and Prejudice in Contemporary American Opinion. In Racialized Politics: The Debate About Racism in America, eds. David O. Sears, Jim Sidanius, and Lawrence Bobo. Chicago: University of Chicago.

Kuhberger, Anton. 1998. The Influence of Framing on Risky Decisions: A Meta Analysis. Organizational Behavior and Human Decision Processes 76(7):23-55.

Kuklinski, James H., Michael D. Cobb, and Martin Gilens. 1997. Racial Attitudes and the 'New South.' Journal of Politics 59(5):323-349.

Lichter, Daniel T., and Martha. L. Crowley. 2002. Poverty in America: Beyond Welfare Reform. Population Bulletin 57(2). Washington, DC: Population Reference Bureau.

Logan, John. 1996. Rural America as a Symbol of American Values. Rural Development Perspectives 12:19-21.

Mendelberg, Tali. 2001. The Race Card: Campaign Strategy, Implicit Messages, and the Norm of Equality. Princeton, NJ: Princeton University Press.

Nelson, Thomas E., Rosalee A. Clawson, and Zoe M. Oxley. 1997. Media Framing of a Civil Liberties Conflict and Its Effect on Tolerance. American Political Science Review 91:567-583.

Nisbett, Richard, and Lee Ross. 1980. Human Inference: Strategies and Shortcomings of Social Judgment. Englewood Cliffs, NJ: Prentice-Hall.

Patel, Dinker I., and Chinna Kanthi. 1986. Rural Poverty in the South: Recommendations Pertaining to Socio-Demographic Factors. In Dimensions of Poverty in the Rural 
South, eds. Jogindar S. Dhillon and Marguerite R. Howie. Tallahassee: Florida A\&M.

Peffley, Mark, Jon Hurwitz, and Paul M. Sniderman. 1997. Racial Stereotypes and Whites' Political Views of Blacks in the Context of Welfare and Crime. American Journal of Political Science 41:30-60.

Quadagno, Jill. 1994. The Color of Welfare: How Racism Undermined the War on Poverty. New York: Oxford University Press.

Schexnayder, Deanna, Daniel Schroeder, Laura Lein, David Dominguez, Karen Douglas, and Freddie Richards. 2001. Texas Families in Transition/Surviving without TANF: A Preliminary Analysis of Families Diverted From or Leaving TANF. Ray Marshall Center for the Study of Human Resources and the Center for Social Work Research, The University of Texas at Austin, and Prairie View A\&M University, Center for Innovative Projects for Economic Development. March. http://www. utexas.edu/research/cshr/rmc1/index.php/publications/all-publications/175-texasfamilies-in-transition.html?catid=7\%3Aabout (July 22, 2011).

Sears, David O. 1986. College Sophomores in the Laboratory: Influences of a Narrow Data Base on Social Psychology's View of Human Nature. Journal of Personality and Social Psychology 51:515-530.

Sears, David O., P.J. Henry, and Rick Kosterman. 2000. Egalitarian Values and Contemporary Racial Politics. In Racialized Politics: The Debate About Racism in America, eds. David O. Sears, Jim Sidanius, and Lawrence Bobo. Chicago: University of Chicago.

Sherman, Jennifer. 2006. Coping with Rural Poverty: Economic Survival and Moral Capital in Rural America. Social Forces 85(12):891-913.

Soss, Joe, Laura Langebein, and Alan R. Metelko. 2003. Why Do White Americans Support the Death Penalty? Journal of Politics 65(5):397-421.

Virtanen, Simo V., and Leonie Huddy. 1998. Old Fashion Racism and New Forms of Racial Prejudice. Journal of Politics 60(5):311-332.

Waxman, Chaim I. 1983. The Stigma of Poverty: A Critique of Poverty Theories and Policies, 2nd ed. New York: Pergamon.

Wilson, William J. 1996. When Work Disappears. New York: Knopf. 